\title{
Capacity Building Model of Social Assistance in Improving the Productive Economy of the Poor
}

\author{
Hasmin Tamsah ${ }^{a}$, Gunawan Bata Ilyas ${ }^{b}$, Sirajuddin ${ }^{c}$, Yuswari Nur ${ }^{d}$, \\ Yusriadi Yusriadie, ${ }^{\mathrm{a}, \mathrm{b}}$ Sekolah Tinggi Ilmu Ekonomi Amkop, Makassar, \\ Indonesia, ${ }^{\mathrm{c}} \mathrm{Halu}$ Oleo University, Kendari, Indonesia, ${ }^{\mathrm{d}}$ Sekolah Tinggi Ilmu \\ Ekonomi Nobel Indonesia, Makassar, Indonesia, 'Sekolah Tinggi Ilmu \\ Administrasi Puangrimaggalatung, Makassar, Indonesia,
}

This study aims to explore the influential factors in increasing productive economic endeavours and finding models for developing social assistance in improving productive financial efforts. This study used a descriptive qualitative method with in-depth interviews followed by a focus group discussion of 17 informants in the South Buton District and nine informants in the Kolaka Regency and two key informants from the social service office in Southeast Sulawesi Province. The results showed an increase in the capacity of social assistance to improve the economy of the poor in the districts of South Buton and Kolaka, including education, training, experience, and motivation. The social assistance capacity building model improves the productive economic endeavours of the poor in the districts of South Buton and Kolaka by taking some approaches, including a) Synchronisation and coordination of social ministry programs, provinces, and districts/cities; b) Enhancing necessary skills (making programs, proposals, reports, etc.); c) Increased analytical skills (analysis of raw material requirements, operational analysis, market analysis); d) Increased ability to use media (information, outreach, sharing, promotion, etc.); e) Increasing the capacity of entrepreneurial spirit.

Key words: Development models, social assistance, productive economic enterprises, poor.

\section{Introduction}

The problem of poverty is one of the main issues faced by developing countries, including Indonesia. This issue always debated because of its complex issues. Based on data (BPS, 
International Journal of Innovation, Creativity and Change. www.ijicc.net

Volume 14, Issue 1, 2020

2018), the population with a total expenditure below the poverty line in Indonesia is still around 28.01 million or 10.86 percent, decreasing by only 0.50 million compared to the same condition the previous year (28.51 million or 11.13 percent). While the following one year, which is September 2016, it also decreased to 27.76 million people (10.70 percent). While the next semester, there were 27.77 million people (10.64 percent), although in terms of numbers, they increased, the percentage decreased by 0.06 percent (BPS, 2017).

Various poverty reduction programs are carried out by the government and integrated, starting from social assistance, community empowerment, and small business empowerment. The Government of Indonesia issued Presidential Regulation No. 15 of 2010 to accelerate poverty reduction from 8 percent to 10 percent in 2014. Four basic strategies accelerate poverty reduction, namely: 1) perfecting social protection programs; 2) increasing access of the poor to basic services; 3 ) community empowerment; 4) inclusive development. It is hoped that with this strategy poverty can be overcome in Indonesia.

Based on this strategy, local governments, through institutions in each region, including in the districts of South Buton and Kolaka, have poverty alleviation programs. But the reality is not yet optimal; this is proven to be evenly distributed poverty in all provinces in Indonesia, including in Southeast Sulawesi.

\section{Method}

The study was carried out for six months in 2017 by interviewing 17 informants in the South Buton District, nine informants in the Kolaka District and two key informants from the Southeast Sulawesi Province social service. This study was conducted with a qualitative descriptive method. The research instrument was the researcher himself-data collected through observation, interview, documentation, and Focus Group Discussion techniques. For data validity, this study uses triangulation in data collection techniques.

\section{Result and Discussion}

Factors That Influence the Implementation of Social Assistance Programs in Improving the Productive Economic Efforts of The Poor

Based on the results of research factors that can influence the successful implementation of social assistance in increasing the productive economic efforts of the poor in the South Buton Regency and Kolaka Regency, these include elements of education, training, experience, and internal motivation into the capital in assisting recipients of assistance for the poor in the South Buton Regency and the Kolaka Regency. This view can described as follows: 


\section{Education}

To improve the quality and capacity of the poor in the Law called the poor in the districts of South Buton and Kolaka, knowledge and understanding of the facilitators is well needed. Good knowledge of the program and procedures, as well as the mechanism desired by the program, will facilitate the companion to carry out the task well.

If the companion does not understand it, it isn't easy to run the program correctly. This understanding and knowledge is obtained from formal and non-formal education. The informants in the study had an adequate level of education to understand the whole program even though it was still at a minimum level. Training is beneficial in understanding and running programs; this is in line with the results of studies (Cuslinda, Mattalatta, \& Hasmin, 2015; Rizka, Mujiburrahman, \& Faqih, 2017), that the new vision of education in the future must contain a function as a means of empowerment, investment in human resources, and human capacity development; education and training are carried out by an organisation to improve skills, improve behaviour, develop attitudes, and abilities as desired by the organisation or individual (Kamil, 2012; Rivai, 2008). Owned education can know and understand problems at work, including as a companion. The assistants in the districts of South Buton and Kolaka can carry out their duties and responsibilities because they are equipped with the education they received before. Other research shows that training can improve performance (Barba Aragón, Jiménez Jiménez, \& Sanz Valle, 2014; Okechukwu, 2017; Sandamali, Padmasiri, Mahalekamge, \& Mendis, 2018; Suhartini, 2015). Thus, formal education can help the assistant in completing their duties.

\section{Training}

The results of the research show implementation of assistance influenced by the training of mentors in the form of technical guidance. They get advice before assisting recipients during the process of collecting data, making programs, and preparing proposals. Continuous training will improve performance in the form of formal and non-formal performance. The facilitators who always add knowledge will get good results and make it easier to provide solutions to the problems faced by the beneficiaries they assist. The assistance process is complicated and requires time and patience and is an achievement if it succeeds in helping the community so that the business is thriving. Several studies have shown that training has a positive effect on work performance or employee performance (Dzamesi, 2012; Harudi, Tamsah, \& Gunawan, 2016; Jocom, Lambey, \& Pandowo, 2017; Sandamali et al., 2018; Thevanes \& Dirojan, 2018). Properly run training, appropriate programs, and methods trained according to needs will help trainees improve their performance. Furthermore Rivai, (2004) states that education and training as part of a culture that involves the learning process to 
International Journal of Innovation, Creativity and Change. www.ijicc.net

Volume 14, Issue 1, 2020

acquire and enhance skills and knowledge outside the education system in a relatively short period, aimed at improving current employee performance and future performance.

\section{Experience}

The results showed that an experienced companion would be more comfortable to solve the problem encountered compared to an inexperienced one. Work experience can help someone gain knowledge from what is felt, seen, and done to improve knowledge and skills about suitable work methods (Manullang, 2012; Ranupandojo, Heidjrachman, \& Husnan, 2009). These expert views show the more experienced someone is and the longer a person works, their knowledge increases so that they find it easier to overcome any recurring problems, because there are already references to how to overcome them beforehand. Thus, the more experienced an employee, the better the performance. The results of research (Famella, 2015; Robbins \& Judge., 2008) prove that work experience that is applied in the work or profession of employees will improve employee performance.

\section{Motivation}

Work as a companion is not a profession that is solely carried out to earn income or hope with complete facilities. Still, the business as a companion is a calling of the soul to serve and channel the soul of humanity. The people who are involved in this profession are already feeling enough in material terms and only want to devote themselves to helping others. In some countries, the job as a social worker has enough financial ability so that with that ability, they help others. In Indonesia, people who want to be involved as social workers are still minimal, so the government plays a significant role in handling this problem. The results showed that with high motivation, the companions could improve their performance, giving a strong impetus as a companion to give their best so that their goals are achieved. Indirectly they work to help the poor people they assist. High motivation is believed to influence carrying out their duties as a companion; several studies show the same thing (Fitrianto \& Tamsah, 2016; Harudi et al., 2016; Salama, Tamsah, \& Natsir, 2017; Wahab, Tamsah, \& Munir, 2017). They found that high motivation will improve performance because motivation plays a significant role in encouraging employees to improve their ability to work. Furthermore, Ivancevich, Konopaske, \& Matteson, (2006), Laniwidyanti, Noermijati, \& Thoyib, (2012), Winanti, (2011) stated that work motivation is influenced by the ability of employees and individual experience in working. 
International Journal of Innovation, Creativity and Change. www.ijicc.net

Volume 14, Issue 1, 2020

\section{Model of Capacity Building of Social Assistance in Increasing Productive Economic Efforts of the Poor}

This research shows that the capacity of assistance in efforts to improve the productive economy of the poor in the two research locations is not optimal. Several business failures were experienced by the beneficiaries. Some businesses, such as laying hens, beef chickens, native chicken, and staple businesses in several areas, have failed. They have tried as much as possible to assist but still have not succeeded. Fostering the entrepreneurial spirit of the poor is not optimal. The job as a companion is how to increase the capacity of aid recipients receive to be independent. Capacity building must be carried out continuously until the success rate is higher. Although there are still differences in the understanding and terminology of capacity development, all of them lead to the ability to increase knowledge and skills. It hoped that after their knowledge and skills improve, social attitudes and behaviour change for the better (Cuthill \& Fien, 2005; P. Lacy, John Dougherty, \& D. Gibson, 2002; N. Page, \& Czuba, CE, 1999; N. Page \& Czuba, 1999).

The understanding among group members about the type of businesses that will develop also needs to pay attention to the products to sell by paying attention to those around them, about their needs, so that the product initiated can be successful. Based on the previous findings, there are several things that still need to be considered to be improved, including coordination between facilitators to be able to share knowledge and experience, provide information about the availability of raw materials, efficiency, process effectiveness, and marketing expansion. Also there is the companion's necessary abilities, namely the ability to compile programs, prepare proposals, and make reports. There is also knowledge of analysis, namely the ability to obtain, process, and then decide everything related to the task and responsibility as a companion - the ability to use information technology as a communication tool and a marketing tool for the products produced. The strength of the spirit of entrepreneurship, namely the expertise possessed by a companion in utilising everything that is around him, becomes a business opportunity that will produce added value. This ability is obtained from education, training, and experience. There is also information support, including the capacity to collect, access, and manage user information. In principle, community capacity building is an effort to improve the ability of the community itself.

\section{Conclusion}

Based on the results of research and discussion, this study can conclude that several factors that influence the improvement of the capacity of social assistance in improving the productive economic efforts of the poor in South Buton Regency and Kolaka Regency, include education, training, experience, and motivation. These factors contributed significantly to increasing the capacity of social assistance in the two research areas. 
Education and training that is owned by the facilitator have a considerable role in providing the solutions faced. Furthermore, adequate experience is needed so that the problems faced in guiding can be offering guidance; a high motivation is required to give to the problematic situation, condition, and location in the area of work. The social assistance capacity building model in improving the productive economic endeavours of the poor in South Buton and Kolaka Districts has taken several approaches, including a) synchronising and coordinating the programs of the social ministries, provinces, and districts/cities. b) primary capacity building (making programs, proposals, reports, etc.). c) improvement of analytical skills (analysis of raw material requirements, operational analysis, market analysis). d) increasing the ability to use media (information, socialisation, sharing, promotion, etc.); e) increasing the capacity of the entrepreneurial spirit. 
International Journal of Innovation, Creativity and Change. www.ijicc.net

Volume 14, Issue 1, 2020

\section{REFERENCES}

Barba Aragón, M. I., Jiménez Jiménez, D., \& Sanz Valle, R. (2014). Training and performance: The mediating role of organizational learning. BRQ Business Research Quarterly, 17(3), 161-173. doi: 10.1016/j.cede.2013.05.003

BPS. (2017). Sulawesi Tenggara dalam Angka. from Badan Pusat Statistik, ISSN: 02152304, No. Publikasi/Publication Number: 74560.1701, Katalog/Catalog: 1102001.74.

BPS. (2018). Kota Kendari dalam Angka 2018: Badan Pusat Statistik Kota Kendari.

Bryant, A., \& Charmaz, K. (2010). The SAGE Handbook of Grounded Theory: SAGE Publication Ltd., London.

Bungin, B. H. M. (2007). Penelitian kualitatif : Komunikasi, ekonomi, kebijakan publik, dan ilmu social: Jakarta : Kencana Prenama Media Group.

Chariri, A. (2009). Landasan filsafat dan metode penelitian kualitatif: Fakultas Ekonomi Universitas Diponegoro Semarang.

Creswell, J. W. (2010). Research design pendekatan kualitatif, kuantitatif, dan mixed. Yogyakarya: Pustaka Pelajar.: Yogyakarya: Pustaka Pelajar.

Creswell, J. W. (2013). Qualitative inquiry and research design: Choosing among five appoaches: London: SAGE Publications.

Cuslinda, F. D., Mattalatta, M., \& Hasmin, H. (2015). Pengaruh pengalaman kerja, tingkat pendidikan, budaya kerja, dan kualitas pelayanan terhadap kepuasan pasien pada unit rawat inap rumah sakit stella maris makassar. AKMEN Jurnal Ilmiah, 12(1), 74-82.

Cuthill, M., \& Fien, J. (2005). Capacity building: Facilitating citizen participation in local governance. Australian Journal of Public Administration, 64(4), 63-80.

Dzamesi, C. K. Y. (2012). The effects of training and development on employees' performance in the hunger project - Ghana. A Thesis submitted to the Institute of Distance Learning Kwame Nkrumah University of Science and Technology in Partial Fulfillment of The Requirements for The Degree of Commonwealth Executive Masters of Business Administration.

Famella, S. W. L. H. S., Ana Mufidah. (2015). Pengaruh keterampilan kerja, Pengalaman kerja, dan sikap kerja terhadap kinerja karyawan pada perusahaan Rokok Gagak Hitam Kabupaten Bondowoso. Artikel Ilmiah Mahasiswa 2015. Diunduh tanggal 09 Desember 2017. 
International Journal of Innovation, Creativity and Change. www.ijicc.net Volume 14, Issue 1, 2020

Fitrianto, I., \& Tamsah, H. (2016). Pengaruh motivasi, disiplin, dan kepuasan kerja, terhadap Kinerja Karyawan PT. Bumi Rama Nusantara. Jurnal Mirai Management, 1(1), 85103.

Gutiérrez, M. F. B. M. J. S. P. J. A. T. (1999). Training in small business retailing: testing human capital theory. Journal of European Industrial Training, Vol. 23 Iss 7 pp. 335 352, Permanent link to this document: http://dx.doi.org/10.1108/03090599910287350; doi: 10.1108/03090599910287350; 10.1108/MD-04-2013-0260; 10.1108/03090591211204760.

Harudi, N., Tamsah, H., \& Gunawan, B. (2016). Pengaruh motivasi, disiplin dan kompetensi terhadap prestasi kerja pegawai bagian umum sekretariat daerah kabupaten soppeng. Jurnal Mirai Management, 1(1), 104-118.

Ivancevich, J. M., Konopaske, R., \& Matteson, M. T. (2006). Perilaku dan manajemen organisasi. Jilid Satu, Erlangga, Jakarta.

Jocom, J., Lambey, L., \& Pandowo, M. (2017). The effect of job rotation and training on employee performance in PT. Pegadaian (Persero) Manado. Jurnal EMBA, Vol. 5 No. 2 Juni 2017, Hal. 279 - 288.

Kamil, M. (2012). Model pendidikan dan pelatihan (konsep dan Aplikasi). Bandung: Alfabeta.

Lacy, D. P., Dougherty, M. J., \& Gibson, P. D. (2002). Models of community planning. Paper presented at the Strengthening Communities, Enhancing Cooperative Extension's Role National Community Resources and Economic Development (CRED) Conference, Orlando, Florida, February 25, 2002.

Laniwidyanti, Noermijati, \& Thoyib, A. (2012). Pengaruh hubungan kerja, pengalamn kerja dan motivasi kerja terhadap kinerja karyawan Bank Central Asia (BCA) Cabang Borobudur, Malang. Program Pascasarjana Universitas Brawijaya. Retrieved from http://wacana.ub.ac.id/index.php/wacana/article/view/166, http://wacana.ub.ac.id/index.php/wacana/article/view/166/143

Manullang. (2012). Dasar-Dasar manajemen: Gadjah Mada University Press. Yogyakarta.

Moleong, L. J. (2012). Metodologi penelitian kualitatif edisi revisi: Bandung: PT. Remaja Rosdakarya. 
International Journal of Innovation, Creativity and Change. www.ijicc.net Volume 14, Issue 1, 2020

Ng'ang'a, R., Weru, J. W., A, D. I. M., \& Sakwa, D. M. (2013). The relationship between training and development on performance of state owned corporations. International Journal of Academic Research in Business and Social Sciences, 3(9). doi: 10.6007/IJARBSS/v3-i9/190

Okechukwu, W. (2017). Influence of training and development, employee performance on job satisfaction among the staff of school of technology management and logistics, Universiti Utara Malaysia (STML, UUM). Journal of Technology Management and Business (ISSN: 2289-7224), Vol 04, No 01, 2017.

Page, N., \& Czuba, C. E. (1999). Empowerment: What is it? Journal of extension, 37(5), 1-5.

Peraturan-Presiden. (Nomor 15-2010). Peraturan presiden republik Indonesia Nomor 15 Tahun 2010 tentang Percepatan Penanggulangan Kemiskinan.

Putnam, R. (2000). Bowling alone: The collapse and revival of American Community. New York: Simonand Schuster.

Ranupandojo, Heidjrachman, \& Husnan, S. (2009). Manajemen personalia: Yogyakarta: BPFE.

Rivai, V. (2008). Manajemen sumber daya manusia untuk perusahaan: dari Teori ke Praktik.: PT. Raja Grafindo Persada, Jakarta.

Rizka, M. A., Mujiburrahman, \& Faqih, M. (2017). Pemberdayaan masyarakat melalui Pendidikan Keluarga berbasis posdaya sebagai upaya mewujudkan generasi emas NTB (GEN). Lumbung Inovasi: Jurnal Pengabdian Kepada Masyarakat IKIP Mataram e-ISSN:2541-626X Volume 2 Nomor 1, Oktober 2017.

Robbins, S. P., \& Judge., T. A. (2008). Perilaku organisasi edisi ke-12: Jakarta: Salemba Empat.

Salama, S., Tamsah, H., \& Natsir, M. (2017). Pengaruh pelatihan, motivasi kerja, dan pengembangan karir terhadap prestasi kerja pegawai pada satuan polisi pamong praja kabupaten soppeng. Jurnal Mirai Management, 2(1), 164-174.

Sandamali, J. G. P., Padmasiri, M. K. D., Mahalekamge, W. G. S., \& Mendis, M. V. S. (2018). The relationship between training and development and employee performance of executive level employees in apparel organizations. International Invention of Scientific Journal, ISSN: 2457-0958, www.iisj.in, January, 2018, Volume 02, Issue 01. 
Seleim, A., Ashour, A., \& Bontis, N. (2007). Human capital and organizational performance: a study of egyptian software companies. Management Decision, 45(4), 789-801. doi: $10.1108 / 00251740710746033$

Sugiyono. (2016). Metode penelitian kuantitatif, kualitatif dan R\&D: Bandung: PT Alfabeta.

Suhartini, Y. (2015). Pengaruh pengetahuan, keterampilan dan kemampuan karyawan terhadap kinerja karyawan (Studi pada industri kerajinan kulit di manding, Bantul, Yogyakarta). Akmenika: Jurnal Akuntansi dan Manajemen, 12(2).

Tan, E. (2014). Human capital theory. Review of Educational Research, 84(3), 411-445. doi: $10.3102 / 0034654314532696$

Thevanes, N., \& Dirojan, T. (2018). Impact of training and job involvement on job performance. International Journal of Scientific and Management Research, Volume 1 Issue 1 (July-August) 2018, ISSN:2581-6888, Page: 1-10.

Wahab, W., Tamsah, H., \& Munir, A. R. (2017). Analisis pengaruh motivasi kerja, komunikasi dan lingkungan kerja terhadap kinerja pegawai pada kantor dinas perhubungan komunikasi dan informatika kabupaten soppeng. Jurnal Mirai Management, 2(2), 405-422.

Winanti, M. B. (2011). Pengaruh kompetensi terhadap kinerja karyawan (Survei pada PT. frisian flag Indonesia Wilayah Jawa Barat). Majalah Ilmiah UNIKOM Vol. 7, No. 2 